\title{
EVOLUÇÃO DE BACIAS DE BAIXA ORDEM NOS 41.000 ANOS AP - BRASIL MERIDIONAL
}

\author{
low-order basins evolution during 41,000 years bp - southern Brazil
}

\author{
Julio Cesar Paisani* \\ Marga Eliz Pontelli** \\ Márcia Regina Calegari***
}

\begin{abstract}
Resumo
Apresenta-se evolução de bacias de baixa ordem hierárquica no Planalto de Palmas/Água Doce (sul do Brasil) nos 41.000 anos AP a partir de registros de seção estratigráfica. Descreveu-se unidades litológicas e pedológicas, análise micromorfológica e datação pelo 14C. Identificaram-se unidades litológicas fácies aluvial, colúvio-aluvial, coluvial e tecnogênica; e duas unidades pedológicas (Neossolos). Conclui-se que no final do Pleistoceno Superior, sobretudo nos EIM 3 e 2, o sistema fluvial de baixa ordem hierárquica e o ambiente de encosta se encontravam em equilíbrio dinâmico, registrando apenas um pulso de morfogênese. Nesse período o fundo de vale apresentou agradacão e desenvolvimento de Neossolo flúvico, em fase com paleossolos similares nas proximidades, atestando estabilidade morfogenética de cunho regional. Na passagem para o Holocêno ocorreu intensa morfogênese das encostas e colmatação dos fundos de vale das bacias de baixa ordem, perdurando até cerca de 1.000 anos AP. Coincidindo com esta fase o divisor de águas regional migra para Norte, com desmantelamento das bacias de $1^{\mathrm{a}}$ ordem do rio Chapecózinho (PR), rehierarquização da rede de drenagem e inversão de relevo.
\end{abstract}

Palavras-chave: Paleocanal, Colúvio, Paleossolos, Inversão de relevo, Quaternário continental.

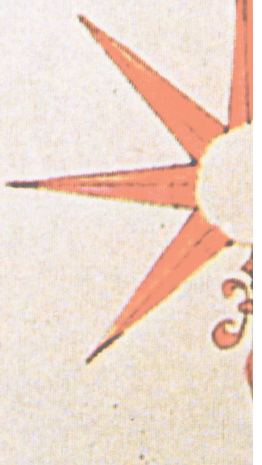

\begin{abstract}
The article presents the low-order drainage basins evolution in Palmas/Agua Doce plateau (South of Brazil) during the last 41,000 years B.P from the registers of stratigraphic section (HS1). Lithological and pedagogical units, micromorphological analysis and dating by $14 \mathrm{C}$ were described. Alluvial facies lithologic, colluvial/ alluvial, colluvial and tecnogenic units were identified; and two pedologycal units (which composed the Entisols). It was possible to conclude that at the end of Upper Pleistocene, especially in MIE 3 and 2, the low hierarchy fluvial system and the slope environment were in dynamic equilibrium, registering just a morphogenesis input. During this period the bottom of valley presented aggradation and development of Fluvisol, in accordance with similar paleosoils nearby, certifying a morphogenetic stability phase in the region. During the transition to the Holocene there was intense morphogenesis from the slopes and catchments aggradation in the bottom of valleys of the low-order basins, extending to about 1,000 years BP. Coinciding with this phase the regional watershed migrates to the North, with consequent dismantling of the 1st order basins of Chapecózinho (PR) river hydrographic system, new hierarchy drainage network and relief inversion.
\end{abstract}

Key words: Palaeochannel, Colluvium, Palaeosoil, Relief inversion, Continental Quaternary.

\begin{abstract}
Resumen
Presentase la evolución de cuencas de bajo orden jerárquico en el Planalto de Palmas/Água Doce (Sur de Brasil) en los últimos 41.000 años A.P. a partir de los registros de la sección estratigráfica HS1. Se hizo la descripción de unidades litológicas y edáficas, análisis micromorfológico y dataciones radiocarbónicas. Se identificaron unidades litológicas facies aluvial, coluvión-aluvial, coluvión y tectogénica, además de dos unidades edáficas constituidas de suelos someros (Leptosol). Se concluye que a lo largo del periodo final del Pleistoceno Superior, sobre todo en los EIM 3 y 2, el sistema fluvial de bajo orden jerárquico y el ambiente de ladera se presentaban en equilibrio dinámico, apuntando a la ocurrencia de solo un evento de morfogénesis. En este período la base del valle pasó por fase de acumulación de sedimentos y de desarrollo de Fluvisoles, muy similares a los paleosuelos semejantes encontrados en otras localizaciones cercanas, señalando la existencia de una fase de estabilidad morfogenética de ámbito regional. En la transición para el Holoceno, hubo fase de morfogénesis muy intensa en las pendientes y acumulación en los fondos de valles de las cuencas de baja orden que se mantuvo hasta cerca de 1.000 anos A.P. En esta misma fase tuvo lugar el proceso de migración del interfluvio regional hacia el norte, resultando en desorganización de las cuencas de $1^{\mathrm{a}}$ orden del sistema hidrográfico del Río Chapecozinho (PR), nueva jerarquización de la red de drenaje y la inversión del relieve
\end{abstract}

Palabras-claves:Paleoincisión, Coluvión, Paleosuelo, Inversión del relieve, Cuaternario continental.

(*) Prof. Dr. do Programa de Pós Graduação em Geografia da Universidade Estadual do Oeste do Paraná, Francisco Beltrão - R. Maringá 1200, CEP: 85.605.010 - Francisco Beltrão (PR), Brasil, Tel. (+55 46) 35204848 - juliopaisani@hotmail.com

(**) Prof ${ }^{\mathrm{a}}$. Dr ${ }^{\mathrm{a}}$ do Programa de Pós Graduação em Geografia da Universidade Estadual do Oeste do Paraná, Francisco Beltrão - R. Maringá 1200, CEP: 85.605.010 - Francisco Beltrão (PR), Brasil, Tel. (+55 46) 35204848 - mepontelli@hotmail.com

(**) Prof ${ }^{\mathrm{a}}$. Dr ${ }^{\mathrm{a}}$ do Programa de Pós Graduação em Geografia da Universidade Estadual do Oeste do Paraná, Francisco Beltrão - R. Maringá 1200, CEP: 85.605.010 - Francisco Beltrão (PR), Brasil, Tel. (+55 46) 35204848 - calegarimarcia1@hotmail.com 


\section{INTRODUÇÃO}

Estudos a respeito da evolução geomorfológica do Estado do Paraná, região sul do Brasil, ganharam destaque no cenário nacional a partir do pioneiro trabalho regional de Reinhar Maack a respeito do clima, solos e vegetação da área (MAACK, 1948). Historicamente, tais estudos foram regionalizados e se concentraram na porção Leste do Estado, sobretudo nas unidades fisiográficas Litoral, Serra do Mar, Planalto de Curitiba e Planalto de Ponta Grossa (AB'SÁBBER e BIGARELLA, 1961; BIGARELLA e SALAMUNI, 1962; BIGARELLA e ANDRADE, 1965; BIGARELLA e MOUSINHO, 1965a; 1965b; BIGARELLA et al., 1965a; 1965b; 1966; 1969; MOUSINHO e BIGARELLA, 1965; ÂNGULO, 1992; ÂNGULO e ABSHER, 1992; PAISANI e OLIVEIRA, 1998; PAISANI e OLIVEIRA, 2001; MELO et al., 2003; SALAMUNI et al., 2004; CAMARGO FILHO, 2005; FORTES et al., 2008). Entretanto, a mesma atenção não foi dada a paisagem da porção Oeste do Estado, cuja unidade morfoestrutural é mantida pelos derrames vulcânicos da Formação Serra Geral - EoCretacea (NARDY et al., 2008). Essa unidade é constituída predominantemente por derrames de natureza básica, distribuindo-se pelos três Estados da Região Sul do país.

O Grupo de Pesquisa Gênese e Evolução de Superfícies Geomórficas e Formações Superficiais, cadastrado no $\mathrm{CNPq}$, vem se interessando em compreender a evolução do relevo nessa unidade morfoestrutural, sobretudo no setor Sul do Paraná e Norte de Santa Catarina (PAISANI et al. 2005; 2006; 2008a; 2008b; 2008c; PONTELLI \& PAISANI, 2008; CALEGARI, 2008; LIMA, 2009; GUERRA \& PAISANI, 2010; PAISANI \& GEREMIA, 2010; PAISANI \& PONTELLI, no prelo). A divisão política desses Estados foi definida ao longo de divisor de águas regional, designado por Maack (1968) de Serra da Fartura, que apresenta relevo com formas fortemente dissecadas pelas drenagens dos sistemas hidrográficos dos rios Iguaçú (PR), ao Norte, e Uruguai (SC), ao Sul. Embora a dissecação seja um limitante na compreensão da evolução do relevo e do reconhecimento de morfologias antigas, especialmente por remover os registros das formações superficiais, constata-se que as áreas de topo se ordenam em escadaria de Leste para Oeste e foram reconhecidas como remanescentes de superfícies incompletamente aplainadas (PAISANI et al., 2008b).

Os processos responsáveis pela elaboração dessa superfície estão em estudo. Até o momento percebe-se que predominam ao longo das superfícies perfis de intemperismo com diferentes espessuras com Nitossolos e Latossolos. A exceção é a superfície que corresponde ao Planalto de Palmas (PR) / Água Doce (SC), cujas formações superficiais guardam registros sedimentares e pedológicos quaternários, sobretudo nas bacias hidrográficas de baixa ordem hierárquica.

A caracterização das formações superficiais tem revelado depósitos de colúvio, colúvio-alúvio e alúvio, bem como solos enterrados. Tais registros levam a pensar em uma área cuja evolução se deu por fases alternadas de estabilidade e instabilidade ambiental. Somado a esses fenômenos morfodinâmico, registram-se casos de inversão de relevo, aumentando a complexidade evolutiva dessa área. Neste contexto, este artigo tem como objetivo principal apresentar e discutir os principais aspectos e processos envolvidos na evolução de bacias de baixa ordem hierárquica no Planalto de Palmas/ Água Doce (sul do Brasil) nos 41.000 anos AP, com base em informação da seção estratigráfica HS1.

\section{MATERIAIS E MÉTODOS}

\section{Localização e caracterização da área de estudo}

O Planalto Palmas/Água Doce se encontra na região Sul do Brasil e corresponde a uma unidade morfológica inscrita na unidade morfoestrutural regional conhecida como Planalto Basáltico da Bacia do Paraná (ALMEIDA, 1956) (Figura 1A). Essa unidade morfoestrutural é mantida por derrames vulcânicos de idade EoCretácea que em conjunto correspondem a Formação Serra Geral (SCHNEIDER et al., 1974). Embora predominem derrames de natureza básica nessa Formação, registram-se no Planalto de Palmas/Água Doce derrames de natureza ácida que correspondem ao 
Membro Palmas (NARDY et al. 2008).

Até o momento, neste planalto, foram identificados dois derrames sobrepostos, um constituído de riodacitos (VOLKMER, 1999) e outro de litologia não identificável em face de sua completa intemperização. O derrame intemperizado é subjacente aos riodacitos e por vezes interpenetra aos mesmos. Exibe fenocristais caulinizados, talvez calcedônea ou feldspatóides alterados, e clastos silicosos residuais decorrentes de vesículas (amigdalas ou geodos). Esses dois derrames exibem inúmeros afloramentos na área de estudo e nem sempre apresentam relação direta com as colinas, ombreiras e fundos de vales, recorrentes na área.

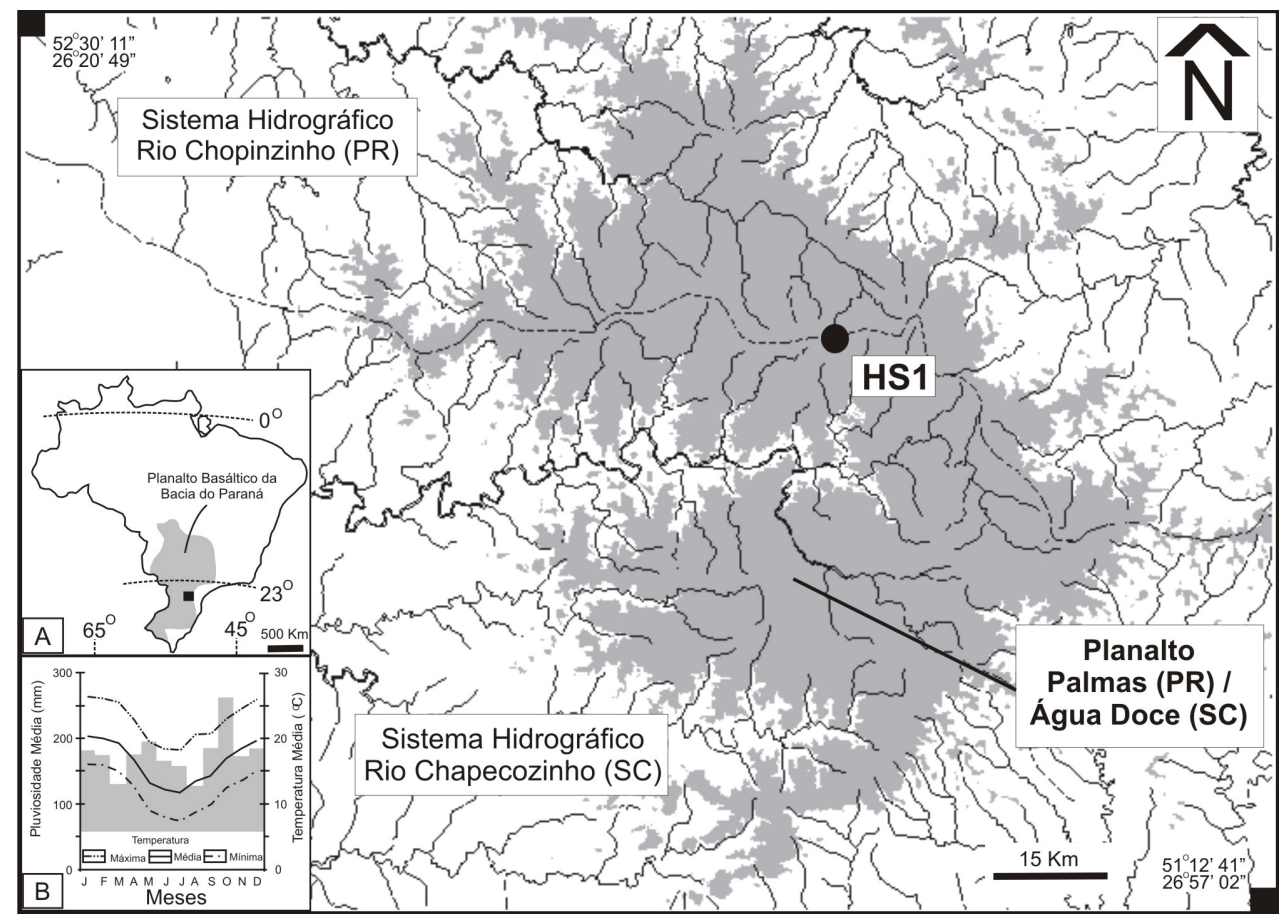

Figura 1 - Planalto de Palmas (PR) / Água Doce (SC). A: Distribuição espacial da Formação Serra Geral. B: Médias de pluviosidade e de temperatura de 1979 a 2009 da estação meteorológica de Palmas (Cód.02651043/IAPAR).

HS1: seção estratigráfica guia dos registros morfodinâmicos da área.

Além dessas morfologias, registram-se na área relevos residuais alongados de topo suavemente convexo que são comuns nas cotas acima de $1.300 \mathrm{~m}$ de altitude. Tais relevos correspondem a remanescentes da superfície de cimeira, designados de Superfície 1 (PAISANI et al., 2008a). Já o nível topográfico que individualiza o Planalto de Palmas /Água Doce equivale a um remanescente de superfície incompletamente aplainada, Superfície 2, que se encontra entre 1.200 e 1.300 m n.m. (PAISANI et al., 2008a). Essas superfícies mantêm um importante divisor de águas regional, que na área de estudo divide as águas que drenam para o sistema hidrográfico do rio Chopinzinho, ao Norte, e para o sistema hidrográfico do rio Chapecózinho, ao Sul; ambos, respectivamente, afluentes dos rios Iguaçú e Uruguai. Esse divisor de águas também é definido como limite político entre os Estados do Paraná e Santa Catarina.

As superfícies incompletamente aplainadas, colinas, ombreiras e fundos de vales exibem formações superficiais delgadas constituídas por colúvios, alúvios e paleossolos, além de localmente Neosolos regolíticos e litólicos com horizonte A húmico.

O clima predominante é temperado sempre úmido com 5 geadas por ano, Cfb na classificação de Köppen, caracterizado por $2.000 \mathrm{~mm}$ anuais de pluviosidade bem distribuída ao longo do ano e estações marcadas por contrastes de temperatura (MAACK, 1968 - Figura 1B).

\section{Descrição de Seção Estratigráfica}

Foram descritas cinco seções estratigráficas e quatro topossequências na área do Planalto de Palmas/Água Doce, dessas a inversão do relevo foi observada nitidamente em três seções. As 
informações mais completas a respeito dos registros estratigráficos e da inversão de relevo foram obtidas na HS1, que se caracteriza como seção guia (Figuras 1 e 2), cujos resultados de sua caracterização são apresentados e discutidos nesse artigo. Essa seção estratigráfica exibe unidades litológicas e pedológicas. As primeiras foram descritas com base nos seguintes procedimentos: a) individualização e denominação das camadas por algarismos romanos da base para o topo; b) tipo de contato entre as camadas; c) estratificação; d) bioturbação; e) presença de raízes; f) seleção, em função da relação entre os tamanhos dos clastos; g) matriz; h) gradação; e i) cor da matriz (Carta de MUNSELL). Em relação aos clastos maiores que seixo fino, descreveu-se: a) constituição; b) arredondamento e esfericidade, conforme Pettijohn et al., (1987 apud NICHOLS, 1999); c) cor, por meio da Rock Color Charth; c) grau de meteorização; e d) constituintes. As descrições foram sintetizadas e classificadas em litofácies. Como a literatura não traz modelos e códigos para fácies de depósitos coluviais de forma padronizada, adaptando-se a nomenclatura de Ghibaudo (1992), já utilizada na região da área de estudo em trabalho anterior (PAISANI e GEREMIA, 2010). A textura da matriz de amostras selecionadas foi estabelecida para completar a caracterização textural das fácies. A determinação foi realizada no Lab. Análise de Formações Superficiais da UNIOESTE, Campus Francisco Beltrão, utilizando-se peneiramento para fração grossa e pipetagem para fração fina, com separação via úmida entre ambas (SUGUIO, 1973).

As unidades pedológicas foram descritas considerando-se: i) cor (Munsell Soil Chart); ii) estrutura; iii) consistência; iv) porosidade; v) transição inferior; e vi) presença de feições pedológicas. Igualmente às unidades litológicas, a textura foi determinada em laboratório. Em relação à unidade pedoestratigráfica 1 (UP1), estabeleceu-se análise micromorfológica visando verificar se as condições de saturação reinantes durante sua formação se mantiveram até o evento morfogenético subseqüente.
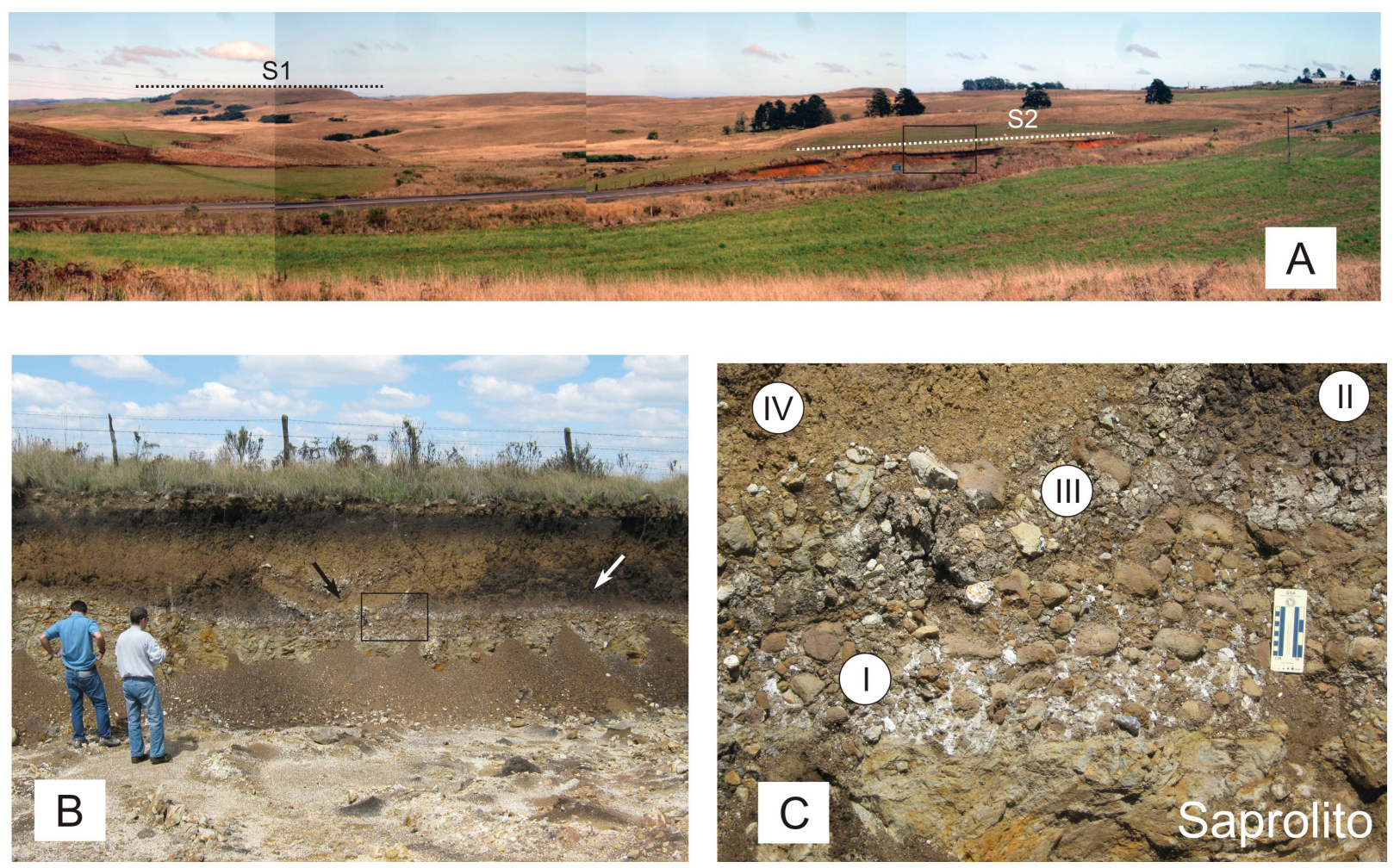

Figura 2 - Contexto da seção estratigráfica HS1 na paisagem do Planalto de Palmas (PR) / Água Doce (SC). (A) Vista da paisagem onde se nota relevos residuais, cujo topo correspondem a Superfície Aplainada 1 (S1), e a seção estratigráfica HS1 localizada na Superfície Aplainada 2 (S2). (B) Vista da seção HS1, onde se destacam paleossolo enterrado (seta preta) e paleocanal (seta branca); e retângulo localiza o detalhe dos contatos. (C) Detalhe do contato das principais unidades litológicas identificadas na seção. I, II, III, IV: unidades litológicas. 
Visando a correlação das informações das unidades litológicas e pedológicas da seção estudada com as demais seções estratigráficas em fase de levantamento na área de estudo, procedeu-se a sistematização e representação das informações em seção colunar utilizando-se dos critérios conjugados da lito-, pedo-, crono- e aloestratigrafia como recomendado por Hugles (2010).

\section{Cronologia do Registro Estratigráfico}

As unidades II e VI, por apresentarem horizontes A húmico, ricos em matéria orgânica, assim como as pedorelíquias do horizonte A enterrado, encontradas na base da unidade IV, foram submetidas a datação pelo 14C no Lab. Beta Analytic Inc. (Miami-EUA), utilizando-se a técnica AMS (accelerator mass spectrometry).

As areias da unidade I, conglomerado com seixos suportados, foram extraídas e submetidas a datação por LOE, porém a baixa qualidade do sinal da dose irradiada pelos grãos analisados produziu uma datação subestimada. Assim, a idade LOE obtida para a unidade I não será apresentada neste artigo.

\section{RESULTADOS}

\section{Individualização de Unidades e Reconhecimento de Fácies Ambiental}

A seção exibe cerca de $50 \mathrm{~m}$ de extensão lateral por aproximadamente $2,7 \mathrm{~m}$ de altura (Figura 3). As unidades estratigráficas têm $0,60 \mathrm{~m}$ a $2,30 \mathrm{~m}$ de espessura, sendo mais espessa na porção central da seção que nas laterais. Esses materiais fazem contato abrupto com o saprolito de derrame vulcânico de natureza ácida, riodacito segundo Volkmer (1999). O saprolito tem cor vermelha pálida (2.5 YR 6/2) com manchas bruno avermelhadas (2.5YR 5/3) a bruno forte (7.5 YR 4/6) circundando as fraturas. Estas últimas são predominantemente subhorizontais (Figuras $1 \mathrm{e} 2 \mathrm{~B}$ ).

A unidade litoestratigráfica I se encontra na base da seção e se assenta em contato erosivo sobre o saprolito do riodacito (Figuras 2 e 3). Corresponde a cascalho lamoso maciço com clastos suportados (m2MyG), é pobremente selecionada e com ausência de gradação. Os clástos suportados estão concentrados a uma proporção de 1,56 clásto.cm-2, são subarredondados, com baixa esfericidade, parcialmente intemperizados, chegando a apresentar menos de $1 \mathrm{~cm}$ de córtex de alteração vermelho acinzentado (HUE 5R 4/2). Predomina seixo grosso com uma classe submodal de seixo médio. Os clástos são constituídos de riodacito com 15\% de fragmentos de calcedônia e clastos residuais silicosos (amigdalas/geodos), conferindo uma natureza oligomítica face os dois últimos serem componentes da mesma fonte litológica, o derrame intemperizado. A matriz mostra-se com coloração esbranquiçada expressando a constituição predominantemente de caolinita. Tais propriedades associadas à geometria do contato basal sugerem que se trata de conglomerado assentado sobre o talvegue de um paleocanal fluvial, de $2^{\mathrm{a}}$ ordem hierárquica, do sistema hidrográfico do rio Chopinzinho (PR). Assim, trata-se de um depósito aluvial (om2MyG-A). 


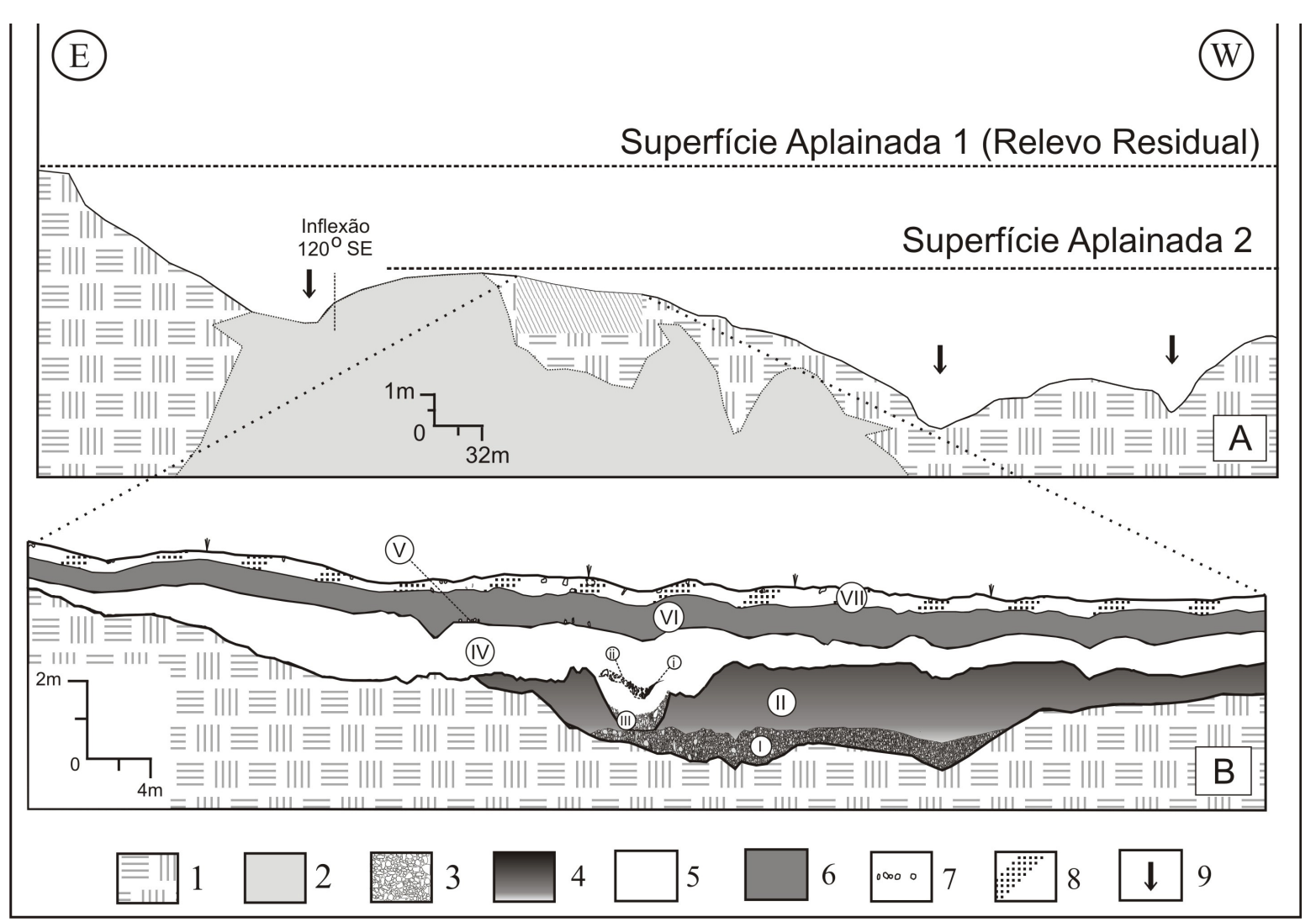

Figura 3 - Reprodução da seção lito-pedoestratigráfica. (A) Perfil topográfico e geológico, onde se nota que a seção estratigráfica se encontra na Superfície Aplainada II e tem como substrato o riodacito. (B) Seção estratigráfica com individualização e denominação das unidades por algarismos romanos da base para o topo. Nota-se paleossolo (unidade II) truncado por canal colmatado (unidades III e IV).1: riodacito. 2: derrame intemperizado siltácio. 3: depósito aluvial constituído de cascalho lamoso maciço com clastos suportados (om2MyG-A). 4: depósito colúvio-aluvial pedogenizado constituído de lama (mMyG-AC), com horizonte hidromórfico. 5: depósito coluvial constituído de lama (m2M-C). 6: depósito coluvial pedogenizado constituído de lama (mM-C). 7: depósito de colúvio retrabalhado, linha de pedras descontínua, constituída de cascalho lamoso maciço com matriz suportada (om1MyG-C). 8: depósito tecnógeno constituído de lama cascalhenta com matriz suportada (om1GyM-T). 9: canal intermitente. I, II, III ...: unidades litoestratigráficas. i: lama $(\mathrm{mM})$. ii: cascalho lamoso maciço com matriz suportada (om2MyG).

A unidade II se caracteriza como lama $(\mathrm{mM})$ com textura variando de argila à lama levemente argilosa (E-VI a D-IV - diagrama de Flemming, 2000). Exibe grânulos esparsos constituídos de litorelíquias de riodacito e fragmentos de calcedônia distribuídas de forma aleatória, imprimindo ausência de gradação (Figuras 2 e 3). Na base registra-se incorporação de alguns cascalhos da unidade subjacente. Essa unidade foi pedogenizada e desenvolveu horizontes A húmico e $\mathrm{Cg}$. O horizonte A húmico registra cerca de 65 g.kg-1 de matéria orgânica, cujo teor decresce em profundidade (OLIVEIRA et. al., 2010). Exibe cor bruna escura (7.5 YR 3/2), estrutura em blocos subangular bem desenvolvida de $4 \mathrm{~cm}$ de comprimento, muito pegajoso, pouco plástico, com cerca de $10 \%$ de microporos tubulares e - $40 \%$ de macroporos fissurais. A transição inferior é clara para horizonte $\mathrm{Cg}$, hidromórfico de cor acinzentada, de $0,30 \mathrm{~m}$ de espessura (Figuras 2 e 3 ). A análise micromorfológica revelou que o horizonte A exibe forte bioturbação e remobilização de ferro associada à duas fases: $1^{a}$ ) sutil remobilização de ferro decorrente de hidromorfismo constante e $2^{a}$ ) remobilização de ferro mais pronunciada vinculada a período de dessecação/ umectação (oxidação/redução). Nesta última fase foram geradas gretas de contração, reconhecíveis em escala microscópica, com preenchimento denso entre as fendas (Figura 4). Tais fases de remobilização de ferro indicam mudanças no regime hídrico do horizonte A, passando de um estágio de constante hidromorfismo (encharcamento) para outro de sazonalidade hídrica. 

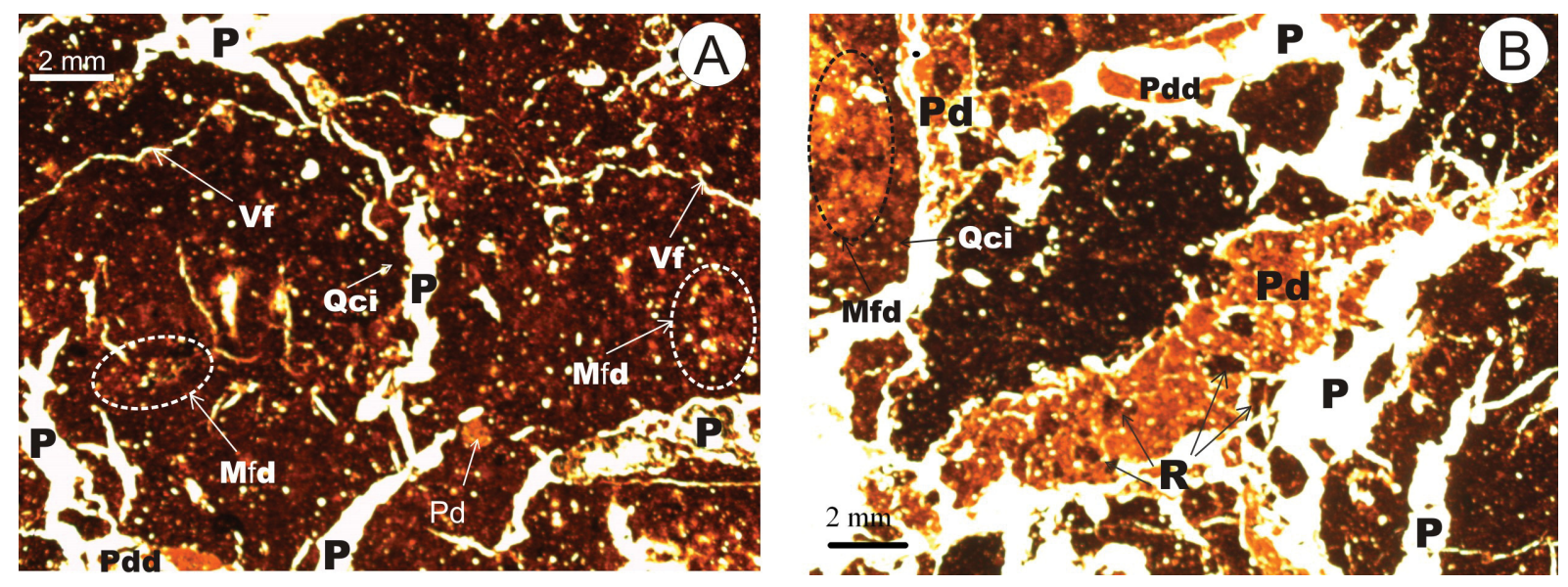

Figura 4 - Fotomicrografias da unidade pedoestratigráfica 1 (UP1) capturadas sobre luz polarizada plana. A: Fundo matricial porfírico com depleção localizada associada a primeira fase de remobilização de ferro. B: Poros biogênicos preenchidos por material iluvial de greta de contração contendo pedorrelíquias (R) e a segunda fase de depleção de ferro. Nota-se o desenvolvimento de microfeição de depleção mátrica (Mfd), quasicutãs de impregnação de poro concentrando ferro (Qci). Vf: poro fissural. Pd: preenchimento denso contínuo. Pdd: preenchimento denso descontínuo. P: pedotúbulo. Terminologia de Stoops (2003), adaptada para o Português, e lâmina do acervo do Lab. de Microscopia Ótica da UNIOESTE, Campus Francisco Beltrão.

Em relação ao ambiente sedimentar dessa unidade litoestratigráfica, classicamente a disposição de uma unidade de lama (pelítica) sobre outra conglomerática, gerada em ambiente fluvial, é interpretada como uma associação de litofácies de um mesmo ambiente deposicional, no caso, o ambiente fluvial e revela a redução na energia do fluxo do respectivo canal fluvial. Por outro lado, deve-se considerar que em fundos de vales de canais próximos as nascentes, como é o caso da seção estudada, há uma interação entre os processos gerados nas encostas e a sedimentação fluvial (SELBY, 1994). De modo que, fluxos de terra podem colmatar canais de baixa ordem hierárquica, como é o caso de canais de $1^{\mathrm{a}}$ e $2^{\mathrm{a}}$ ordens (MELLO, 1992), registrando interrelação entre os ambientes de encosta e fluvial, sobretudo próximo dos vales de baixa hierarquia (DIETRICH \& DUNNE, 1993). Assim, acredita-se que as propriedades da unidade II sejam resultantes dessa interação entre os ambientes de encosta e fluvial, e revelem a redução da morfogênese tanto nas encostas quanto no canal fluvial. Neste sentido, a unidade II é interpretada como depósito colúvio-aluvial pedogenizado (mM-AC).

A unidade III corresponde a cascalho lamoso maciço com clastos suportados (m2MyG), pobremente selecionados, matriz lama levemente arenosa siltosa e com ausência de gradação. Está disposto na forma de lente com espessura média de $25 \mathrm{~cm}$, em contato abrupto com as unidades inferior e superior (Figuras 2 e 3). Exibe clástos suportados a uma proporção de 0,7 clásto.cm-2, com forma subangular e esfericidade alta, grau de alteração apresentando córtex de alteração de $1,5 \mathrm{~cm}$ de espessura. Os clástos são constituídos de litorrelíquias de riodacito e 14,28\% de fragmentos de calcedônia e clastos residuais silicosos (amigdalas/geodos) - oligomíticos, predominando tamanho de grão na classe seixo grosso. Registra ausência de estratificação e gradação. A matriz mostra-se com cor bruna amarelada escura (10 YR 3/2), enquanto que as litorrelíquias tem o cinza muito claro (N 8) como cor predominante. Tais atributos desta unidade mostram semelhança com a unidade I, diferenciando-se apenas nas dimensões. Assim, a unidade III também corresponde a conglomerado, depósito aluvial (om2MyG-A), assentado sobre o talvegue de um paleocanal, embora de menor dimensão quando comparado com aquele em que se estabeleceu a unidade I.

A unidade IV corresponde a lama $(\mathrm{m} 2 \mathrm{M})$, com textura variando de levemente arenosa argilosa a arenosa muito argilosa (D-IV/D-V), rica em grânulos constituídos de litorrelíquias de riodacito a fragmentos de calcedônia (Figuras 2 e 3). Os grânulos estão distribuídos de forma aleatória impri- 
mindo ausência de gradação. Na extremidade leste da seção, onde a unidade se assenta diretamente sobre o saprolito, registra-se maior concentração de grânulos do que em relação a outros locais da seção. A matriz exibe cor bruna (7.5 YR 4/3), não plástica, é ligeiramente pegajosa e, localmente, exibe pedorrelíquias de um antigo horizonte A. A unidade exibe transição abrupta com as unidades subjacentes (II e IV) e clara com a unidade sobrejacente (VI). Inscrita nesta unidade registram-se duas lentes contíguas de lama (m2M-C) e cascalho lamoso maciço com matriz suportada (om2MyG-C). A primeira exibe cerca de 0,10 de espessura, cor bruna acinzentada muito escura (10 YR 3/2), grânulos de litorrelíquias e fragmentos de calcedônia. Esse material mostra-se duro quando seco, solto quando úmido, ligeiramente plástico e muito pegajoso quando molhado. A primeira lente exibe cerca de 0,25 de espessura, cor bruna escura (7.5 YR 4/2), grânulos de litorrelíquias e fragmentos calcedônia na proporção de 5 a 10\%. Já a segunda apresenta atributos semelhantes aos da unidade III. Pelas características da unidade IV percebe-se se tratar de depósito coluvial (m2M-C) gerado por fluxo de terra de elevada magnitude que recobriu o paleossolo da unidade II, e causou o preenchimento do paleocanal onde se estabeleceu a unidade subjacente. A intensidade do fluxo promoveu a erosão e incorporação de clastos das unidades sobrejacente, unidades II e III, na forma de lentes na porção em que o paleocanal foi colmatado.

A unidade V se caracteriza como linha de pedras descontínua (Figura 2), cuja característica é cascalho lamoso maciço com matriz suportada (m1MyG). A fração cascalho é constituída predominantemente de litorrelíquias de riodacito, a uma proporção de 0,50 clásto.cm-2, mostram-se subarredondados, com baixa esfericidade, parcialmente intemperizados, chegando à apresentar menos de $1,5 \mathrm{~cm}$ a $2 \mathrm{~cm}$ de córtex de alteração, com cor predominante cinza claro médio (N6). Registra-se apenas $20 \%$ de fragmentos de calcedônia o que imprime uma característica oligomítica. Embora na literatura haja diferentes situações que explicam a gênese das linhas de pedra (HIRUMA, 2007), percebe-se que no caso da seção estudada a sua disposição entre duas unidades estratigráficas deixa claro se tratar de uma feição geogenética residual, decorrente de sucessivas fases de erosão de um material previamente depositado, como colocado na literatura clássica (AB 'SÁBBER, 1966). Deste modo, é possível inferir trata-se de um depósito coluvial retrabalhado (om1MyG-C).

A unidade VI apresenta características semelhantes a da unidade IV (Figura 2). É constituída de lama com textura variando de levemente arenosa argilosa a arenosa muito argilosa (D-IV/D-V). Essa unidade sofreu pedogenização e apresenta horizonte $\mathrm{A}$ húmico que transgride as unidades $\mathrm{V}$ e IV. Este horizonte exibe cor preta (7.5 YR 2.5/1), raízes, estrutura fraca em blocos subangulares, consistência: dura, a seco, friável, a úmido e solta, molhado. É pegajoso, plástico, ligeiramente argiloso, cerca de $15 \%$ de macroporosidade fissural e limite sobrejacente claro. Como a unidade apresenta claros sinais de pedogenização, entende-se tratar-se de fácies coluvial pedogenizada (mM-C).

A unidade VII corresponde a depósito tecnógeno, possivelmente gerado quando da abertura da estrada (Figura 2). É constituída de lama cascalhenta com matriz suportada (om1GyM-T), cuja matriz varia de levemente arenosa argilosa a arenosa siltosa (D-III/D-IV), com cor bruna amarelada escura (10YR 4/4) e a fração cascalho é oligomítica. Exibe clastos de seixo médio a grosso, subarredondados a angulosos, com córtex de alteração incipiente, inferior a $0,2 \mathrm{~mm}$ de espessura, dispostos em uma matriz lamosa a uma proporção de 0,1 clásto.cm-2. O contato com a unidade pedogenizada subjacente é abrupto.

\section{Geocronologia e Correlação com Eventos Paleoclimáticos Globais}

As idades por 14C foram obtidas da matéria orgânica contida nas UP1 e UP2, e nas pedorrelíguias encontradas na base da unidade litoestratigráfica IV e são apresentada na Tabela 1. A idade de 41.160 anos AP para a unidade pedoestratigráfica 1 (UP1) apresenta correspondência com o estágio isotópico marinho 3 (EIM3), caracterizado por um período interestadial compreendido entre 58.000 e 25.000 anos AP, cujas temperaturas do Atlântico Sul apontavam para uma tendência de 
aquecimento durante a última glaciação (CORTESE \& ABELMANN, 2002). Pelas características da unidade pedoestratigráfica, acredita-se que na área de estudo, nessa época os depósitos que colmataram a drenagem exibiam condições ambientais que favoreceram a pedogênese em um ambiente hidromórfico. De modo que, o desenvolvimento dessa unidade pedoestratigráfica está em fase com as características do EIM3 que aponta para um aquecimento durante o último glacial, favorecendo condições mais úmidas ao ambiente. Como o horizonte A dessa unidade pedoestratigráfica não foi completamente erodido, pode-se inferir que ele se manteve ativo durante o EIM2, conhecido como Último Máximo Glacial (UMG), mudando de uma fase de pedogênese progressiva para outra regressiva (PHILLIPS, 1993), como evidenciado pela análise micromorfológica.

Tabela 1 - Resultados das idades pelo 14C

\begin{tabular}{|c|c|c|c|c|c|}
\hline Amostra & U.E* & Prof. (cm) & $\delta^{13} \mathrm{C}(\%)$ & $\begin{array}{c}\text { Idade } \\
\text { (anos }{ }^{14} \mathrm{C} \text { A.P.) }\end{array}$ & ${\text { (anos cal. }{ }^{14} \text { C A.P.) }{ }^{1}}^{\text {(ade }}$ \\
\hline Beta-282539 & UP2 & $30-35 /$ L8 & $-14,7$ & $830 \pm 40$ & 800 a 680 \\
\hline Beta-282540 & IV & $160-165 / L 10$ & $-19,2$ & $11.420 \pm 50$ & 13.350 a 13.210 \\
\hline Beta-280518 & UP1 & $150-155 /$ L8 & $-16,8$ & $41.160 \pm 480$ & - \\
\hline
\end{tabular}

U.E.: unidade estratigráfica. *: ver nomenclatura na figura 4. UP: unidade pedoestratigráfica. Ln: locais de amostragem. $12 \sigma, 95 \%$ de probabilidade.

A idade obtida a partir das pedorelíquias foi de 11.420 anos A.P. (13.350 - 13.210 anos cal. A.P.), correspondendo ao EIM 1, referido como Holoceno na escala de tempo geológico (CORTESE \& ABELMANN, 2002). Isso leva a pensar que no ambiente de encosta, no lapso de tempo entre as duas datações, não houve taxa significativa de erosão do horizonte A, evidenciando que a pedogênse prevaleceu sobre a morfogênese. Condição semelhante pode ser inferida para o segmento de fundo de vale onde a UP1, apesar de trucada pelo paleocanal, apresenta-se com horizonte A significativamente espesso, $50 \mathrm{~cm}$. Assim, a área de estudo não apresentou significativa ação da morfogênese nas encostas durante o EIM 2 (UMG), registrou-se apenas uma retomada erosiva da drenagem promovendo o truncamento local da unidade UP1.

$\mathrm{Na}$ amostra datada da UP2, obteve-se 840 anos A.P. (800 - 680 cal. A. P.). Esse valor registra a cronologia de dois fatos importantes do registro estratigráfico: 1) o lapso de tempo da degradação das encostas e agradação dos fundos de vales e 2) o início do desenvolvimento da pedogênese que perdura até os dias atuais. Confrontando essa idade com o início da morfogênese verificada após 11.420 anos A.P., observa-se que o registro estratigráfico mostra que durante o EIM 1, Holoceno, ocorreram múltiplas fases de coluvionamento nas encostas e a colmatação do fundo do paleovale. Essa fase de intensa morfogênese nas encostas, desequilíbrio paleoambiental, também foi registrada em outras áreas planálticas dos Estados do Paraná, Santa Catarina e na região sudeste do país (MEIS e MONTEIRO, 1979; MOURA e MEIS, 1980; MOURA e MELLO, 1991; MODENESI-GAUTTIERI, 2000; MELO et al., 2001; MELO et al., 2003; OLIVEIRA et al., 2006).

\section{DISCUSSÃO}

\section{Fases de Morfogênese e Pedogênese}

O registro estratigráfico da HS1 traz importantes informações a respeito da morfogênese e da pedogênese da área de estudo nos últimos 41.000 anos AP, durante o Pleistoceno Superior (EIM 3 e 2) e Holoceno (EIM 1), documentando fases de instabilidade e estabilidade dos ambientes de encosta e fundo de vales de baixa ordem hierárquica. Tal registro estratigráfico revela que a área passou por uma morfodinâmica não registrada até o momento no Planalto de Palmas (PR)/Água Doce (SC) e 
destoa das formações superficiais encontradas nas demais superfícies aplainadas identificadas ao longo da unidade morfoestrutural em que está inserida (Paisani et al., 2008). A caracterização dos fatos estratigráficos revelou sete unidades litoestratigráficas e duas unidades pedoestratigráficas; que juntas constituem duas sequências cronoestratigráficas e cinco aloformações (Figura 5).

As aloformações A e B foram geradas durante o Pleistoceno Superior, enquanto que as demais C, D, E se formaram durante o Holoceno (Figura 5). A sequência pleistocênica exibe unidades litológicas fácies aluvial e colúvio-aluvial geradas pela sedimentação episódica. Durante o estabelecimento da aloformação A registra-se um paleocanal, de $2^{\mathrm{a}}$ ordem hierárquica, que cujos atributos sinalizam perda de energia de transporte do leito principal durante o período interestadial do último glacial, entre 58.000 e 24.000 anos AP (EIM 3). Essa perda de energia é corroborada face ao fato da dinâmica fluvial não ter tido competência para erodir a porção superior da aloformação que veio a ser pedogenizada (UP1) ulteriormente. A pedogênese levou a formação de Neossolo flúvico com horizonte A húmico fortemente bioturbado e com mobilização de oxihidróxidos de ferro e horizonte subsuperficial hidromórfico, processo típico de ambiente redutor similarmente aos brejos encontrados na atualidade em fundos de vales colmatados. A diminuição da competência do canal aponta para um fato importante, a agradação do paleocanal acompanhada da redução do nível de base local. Esse fato não é exclusivo da seção estratigráfica estudada. Ele também foi observado em outras seções na área de estudo, demonstrando a colmatação da rede de drenagem de baixa ordem do sistema hidrográfico do rio Chopinzinho (PR), podendo ter iniciado antes do interestadio do último glacial (EIM 3).

Critérios Estratigráficos

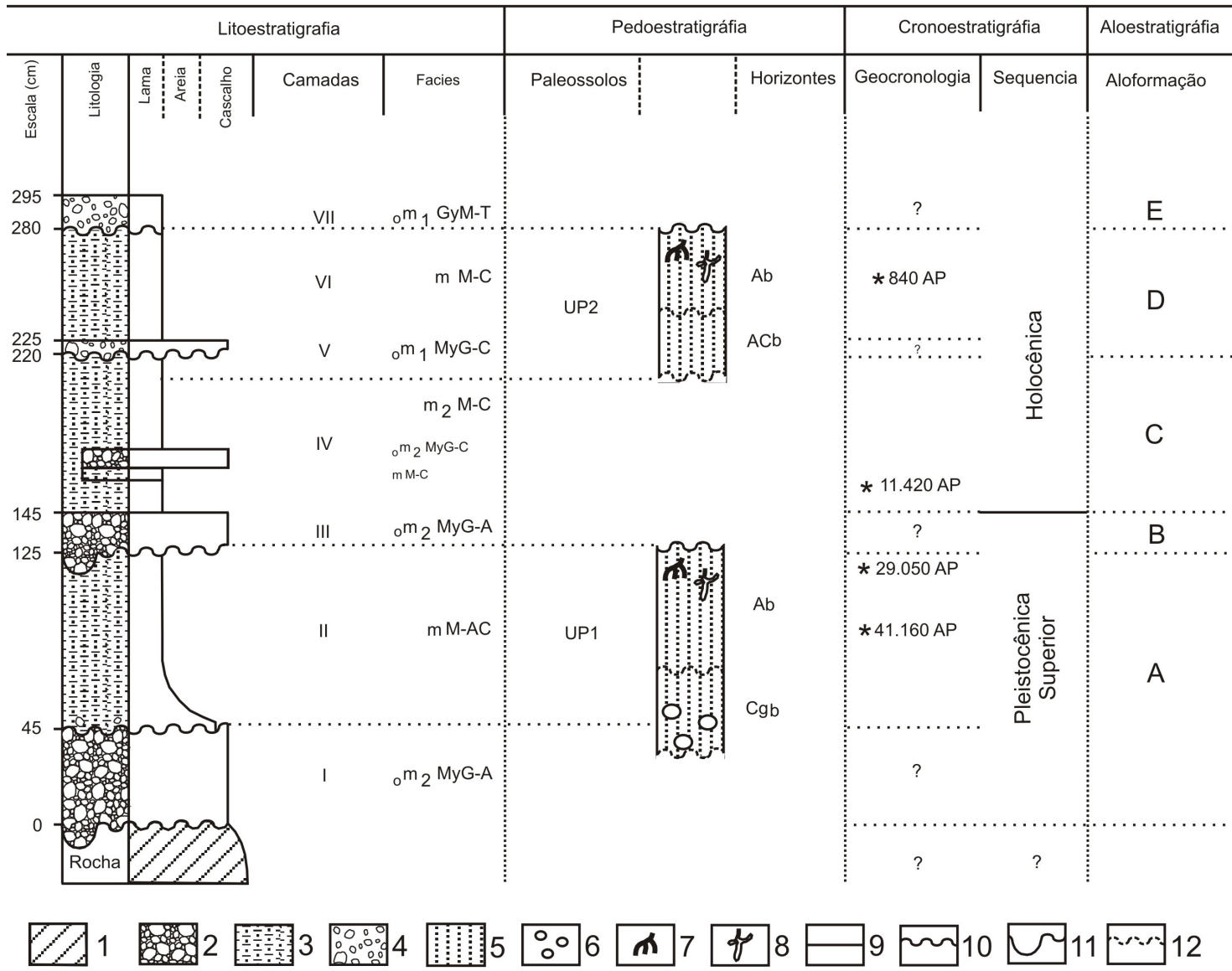

Figura 5 - Estratigrafia da HS1. 1: saprolito do riodacito. 2: cascalho lamoso macio com clastos suportados. 3: cascalho lamoso com matriz suportada. 4: lama cascalhenta com matriz suportada. 5: horizontes pedológicos. 6 : manchas de hidromorfia. 7: raízes. 8: bioturbação. 9: contato abrupto. 10: contato erosivo. 11: contato erosivo. 12: contato claro com incisão de canal. Fácies consultar legenda figura 2. UP: unidade pedoestratigráfica. A: horizonte superficial rico em matéria orgânica. AC: horizonte de transição. Cg: horizonte hidromórfico. b: horizonte enterrado. 
O desenvolvimento do Neossolo flúvico esta em fase com paleossolos similares encontrados nos ambientes de encosta e fundo de vale de baixa ordem hierárquica no Segundo Planalto Paranaense e no Planalto Norte Catarinense (CAMARGO FILHO, 2005; OLIVEIRA et al., 2006). Este fato leva a inferir que as condições paleoclimáticas regionais da época de formação do Neossolo flúvico na área de estudo eram parecidas com as atuais.

A morfogênese da rede de drenagem de baixa ordem hierárquica no sistema hidrográfico do rio Chopinzinho foi retomada durante o EIM 2, Último Máximo Glacial, quando se registra incisão erosiva de um novo paleocanal de drenagem e o estabelecimento da aloformação B. Tal aloformação aponta para o desenvolvimento de um paleocanal de pequenas dimensões estabelecido sobre o Neossolo flúvico (UP1), que pode representar: a) retomada erosiva por mudanças no nível de base local; b) concentração de água do escoamento superficial durante uma fase climática mais seca; ou c) ambas as situações. Como a aloformação B corresponde a conglomerados aluviais gerados em regime subaquoso de fluxo com forte energia, suporta a primeira hipótese. Corroborando para essa idéia tem-se o fato de pedorelíquias de paleohorizonte A terem sido encontradas na unidade litolóligca sobrejacente (IV - Figura 5), as quais mostram a presença de horizonte superficial nos solos das encostas até o início do Holocêno. Esses fatos sugerem que a incisão da rede de drenagem não foi acompanhada de significativa erosão nas encostas circundantes e pode representar a retomada erosiva por variação do nível de base.

Em relação a seqüência Holocênica, à exceção da aloformação E que foi gerada por ação antrópica (tecnogênica), as demais documentam sinais de intensa atividade de degradação das encostas e retrabalhamento de unidades coluviais durante o Holocêno. Destacam-se as unidades litológicas IV (aloformação C) e VI (Topo da aloformação D) que registram eventos individuais de alta magnitude com grande poder de degradação das encostas, os quais se estenderam até o fundo de vale, colmatando-o. A intensidade do evento promoveu a incorporação na unidade IV de lentes de sedimentos proveniente da erosão das aloformações subjacentes. Na base dessa unidade registram-se pedorrelíquias de um paleohorizonte A desenvolvido no ambiente de encosta. Elas atestam que nas encostas a pedogênese atuou, pelo menos, desde os últimos 11.420 anos A.P. Tal cronologia sugere que o evento individual de alta magnitude ocorreu após esse período, no início do Holocêno.

A unidade litológica $\mathrm{V}$, base da aloformação $\mathrm{D}$, caracterizada como linha de pedras descontínua, documenta múltiplos episódios de degradação das encostas e do fundo do vale, por processos de erosão por movimento de massa e escoamento laminar, não se descartando a hipótese de retrabalhamento das unidades coluviais. Nesse momento a morfogênese torna-se um processo predominante e contínuo na evolução das encostas e dos fundos dos vales de baixa ordem hierárquica. A sedimentação da unidade VI, topo da aloformação $\mathrm{D}$, também relacionada a evento individual de alta magnitude, registra o final da ação morfogenética e conseqüente estabilidade local, condicionando o desenvolvimento de uma estreita faixa de material pedogenizado, classificado atualmente como Neossolo (UP2) (EMBRAPA, 2006). Embora essa unidade esteja enterrada na seção estudada, ao longo do Planalto corresponde ao solo moderno, intensamente utilizado para atividades agropastoris. Os dados da datação sugerem que essa estabilidade ocorreu no último milênio.

Enfim, a expressiva morfogênese das encostas registrada durante, ou por boa parte do Holocêno, não havia sido documentada no Planalto de Palmas (PR) / Água Doce (SC), tampouco nem em escala regional. Até o momento há registros de sedimentação durante o Holocêno Médio na região de Ponta Grossa (Melo et al., 2003), situada na unidade fisiográfica regional designada no Paraná de Segundo Planalto Paranaense, e no Planalto Norte Catarinense (Oliveira et al., 2006), ambas associadas a um paleoclima mais seco que o atual.

Inversão de Relevo

A inversão de relevo na área de estudo é nítida e foi constatada inicialmente pela disposição da seção estratigráfica em relação a topografia atual (Figuras 2 e 3). As estruturas de corte e os 
sedimentos conglomeráticos são fortes indícios de duas fases de entalhe fluvial naquele local e apontam para uma paleotopografia no passado geológico recente, diferente da hodierna. Atualmente a seção estratigráfica se encontra em um divisor de águas regional, mas no passado funcionava como fundo de vale assimétrico de canal de $2^{\mathrm{a}}$ ordem hierárquica do sistema hidrográfico do rio Chopinzinho (PR), o qual sofreu duas fases de dissecação intercaladas por colmatações (Figura 3). A inversão de relevo não é exclusiva da seção estudada e exibe caráter regional, havendo registros em outras localidades no Planalto Palmas (PR) / Água Doce (SC), conforme constatado pelo grupo em campanhas de campo mais recentes.

Esse fenômeno promoveu o recuo do divisor regional para o norte, diminuindo a área drenada pelo sistema hidrográfico do rio Chopinzinho (PR) (Figura 6). Como conseqüência houve o desmantelamento dos canais de $1^{a}$ ordem que se ramificaram a partir do tronco de drenagem principal prévio, a partir do qual se formou uma nova hierarquização desse conduto principal, que passou de $2^{\mathrm{a}}$ para $1^{\mathrm{a}}$ ordem hierárquica (Figura 6 ).

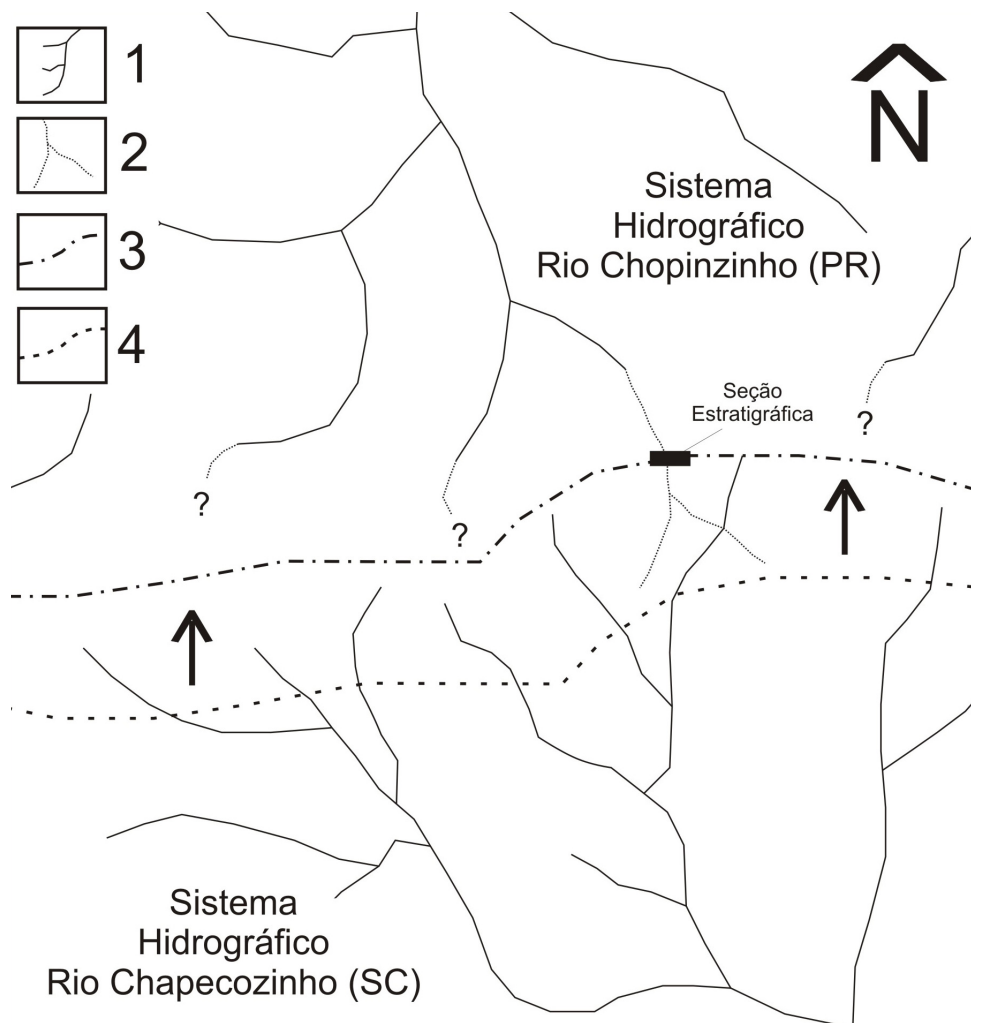

Figura 6 - Esboço mostrando o recuo do divisor regional em direção ao sistema hidrográfico do rio Chopinzinho (PR). 1:drenagem atual. 2:estimativa da paleodrenagem de $1^{\mathrm{a}}$ e $2^{\mathrm{a}}$ ordens. 3:divisor de água atual. 4:estimativa do paleodivisor regional de águas. ?: não verificado.

A inversão do relevo foi produzida pela erosão remontante dos canais de $1^{\mathrm{a}}$ ordem hierárquica da bacia hidrográfica do rio Chapecozinho (SC). A erosão remontante só pode ter sido impulsionada pela variação do nível de base local. Se esse fenômeno foi gerado por rebaixamento do próprio nível de base local ou por um ajuste do nível de base, em conseqüência de soerguimento das áreas próximas aos divisores de água regional, ainda é uma questão em aberto. De todo modo, a incisão dos canais de $1^{\mathrm{a}}$ ordem da bacia do rio Chapecozinho (SC), promoveu o rebaixamento do lençol freático favorecendo o isolamento da seção estratigráfica HS1. Tal fato leva a pensar que a neotectônica tenha sido responsável por tais variações no nível de base. Hipótese essa que atualmente se baseia em evidências circunstanciais, mas que deve ser seriamente considerada, pois há registros da ação da neotectônica influenciando a morfogênese de sistemas hidrográficos de diferentes ordens hierárquicas no Estado do Paraná durante o Pleistoceno Superior e o Holocêno (SALAMUNI et al., 2004; FORTES et al., 2005). 
A seqüência cronoestratigráfica holocênica, caracterizada por unidades litológicas coluviais, não foi afetada pelo evento de inversão de relevo, o que conduz a duas hipóteses a respeito do momento dessa inversão do relevo: 1) a inversão teria se iniciado após a sedimentação da unidade VI; ou 2) teria se iniciado durante a sedimentação da seqüência superior e se efetivado após a sedimentação de tais unidades. Considerando que a incisão de uma rede de drenagem demanda tempo, e tendo por base a idade da UP2 $(<1.000$ anos AP), acredita-se que a segunda hipótese seja a mais provável. De todo modo, não resta dúvida de que a inversão do relevo se processou durante o Holoceno e foi a reponsável pelo final da sedimentação natural no local da seção estratigráfica. $O$ único evento sedimentar posterior se deve a ação antrópica, como evidenciada na unidade VII.

\section{Evolução de Bacias de Baixa Ordem Hierárquica nos 41.000 anos A.P.}

A partir das interpretações dos resultados a cerca da estratigrafia da seção guia do Planalto de Palmas (PR) / Água Doce (SC), balizadas porinformações de outras seções estratigráficas não apresentadas nesse trabalho, é possível esboçar um modelo de evolução das bacias de baixa ordem hierárquica aplicável, inicialmente, para o sistema hidrográfico do rio Chopinzinho (PR).

Antes de 41.000 anos AP o divisor de águas regional foi mantido, principalmente, pelos relevos residuais que constituem a Superfície Aplainada 1 (S1). Nessa época ele se estendia mais para o sul onde hoje se encontram as bacias de $1^{\mathrm{a}}$ ordem hierárquica do sistema hidrográfico do rio Chapecózinho (SC). Enquanto que os atuais canais de $1^{a}$ ordem do rio Chopinzinho (PR) eram de ordem hierárquica superior e funcionavam como troncos principais das bacias hidrográficas de $2^{\mathrm{a}}$ ordem hierárquica desse sistema (Figura 7A). Os vales de tais canais por vezes, podem ter sido assimétricos, à exemplo do caso da HS1, onde o tronco principal drenava água e sedimentos na forma de um canal perene, cujo fundo do canal se estabelecia diretamente sobre o riodacito. $\mathrm{O}$ canal se caracterizava como de alta energia acumulando em seu leito conglomerados decorrentes de variações no regime hídrico (Figura 6A). Neste mesmo período, predomina na a pedogênese nas encostas atuando, juntamente com o intemperismo na alteração do embasamento formando, possívelmente, solos mais profundos, como aqueles classificados atualmente como Argissolos (EMBRAPA, 2006), mantendo um horizonte A húmico, com elevada concentração de carbono orgânico. O tempo de estabilidade morfodinâmica não pode ser determinado, mas com base nas estimativas de tempo de formação de horizonte argílico estima-se que deveria ser da ordem de 1.000 a 10.000 anos (BORCHARDT, 2002).

Tal estabilidade foi rompida próximo à 41.000 anos AP, por evento individual de alta magnitude que entulhou o tronco principal dessas bacias. Esse pulso de instabilidade com a colmatação do fundo de vale se estendeu para jusante nos segmentos de canais de maior ordem hierárquica, reduzindo o nível de base local das bacias de baixa ordem hierárquica (Figura 6B). A vegetação passa a ocupar o fundo de vale e a drenagem preferencial passa a ser hipodérmica. Nesse local desenvolvem-se solos semelhantes aos atuais, Neossolos flúvicos com horizontes $\mathrm{A}$ húmico e $\mathrm{C}$ hidromórfico.

Entre 41.000 e 11.000 anos AP percebe-se sinais de um período de equilíbrio dinâmico (Figura 7B). A pedogênese progressiva pode ter se desenvolvido até cerca de 25.000 anos (est.) A.P., correspondente ao interestádio do último glacial (EIM 3). No decorrer do último máximo glacial (EIM 2) registrou-se uma pedogênese regressiva, na conceituação de Phillips (1993), com dessestabilização do horizonte superficial do solo raso existente (Neossolo flúvico), onde teria passado a ocorrer gretas de dissecação face mudanças no regime hídrico do fundo de vale. A morfogênese passou a atuar de forma mais efetiva no fundo do vale decorrente da retomada erosiva do tronco principal da rede hidrográfica, enquanto que nas encostas o escoamento superficial ocorria em taxas insuficientes para desmantelar completamente os horizontes superficiais, por vezes A húmico (Figura 6B). A pedogênese repressiva do paleoneossolo flúvico dos fundos de vale se deve ao rebaixamento do lençol freático, cuja determinante pode ser: a) paleoclimática, com sazonalidade hídrica bem individualizada; b) captura das águas subterrâneas pelas drenagens das bacias de $1^{\mathrm{a}}$ ordem hierárquica 
dos sistemas do rio Chapecózinho (SC); e c) ambas as ações. Essa fase de equilíbrio dinâmico foi rompida no início do Holoceno ou já na passagem Pleistocêno/Holocêno.

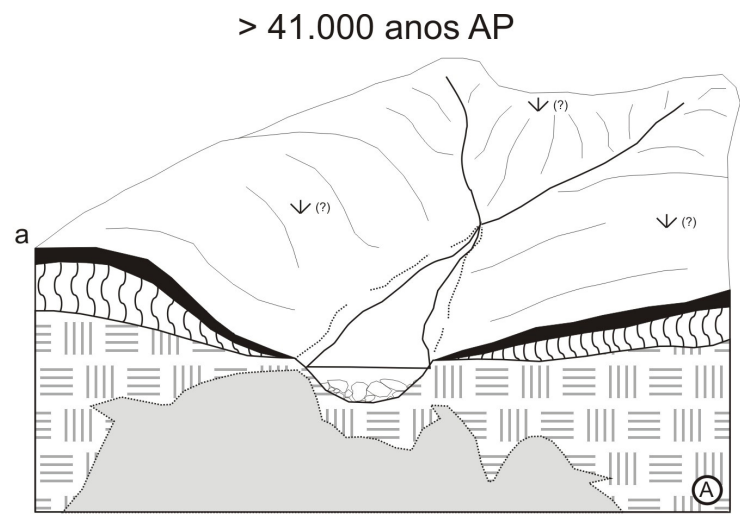

41.000 a 11.000 anos AP

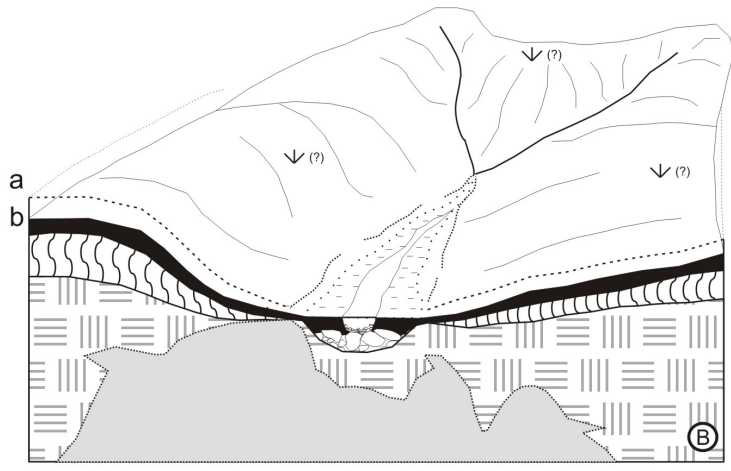

11.000 AP ao Atual
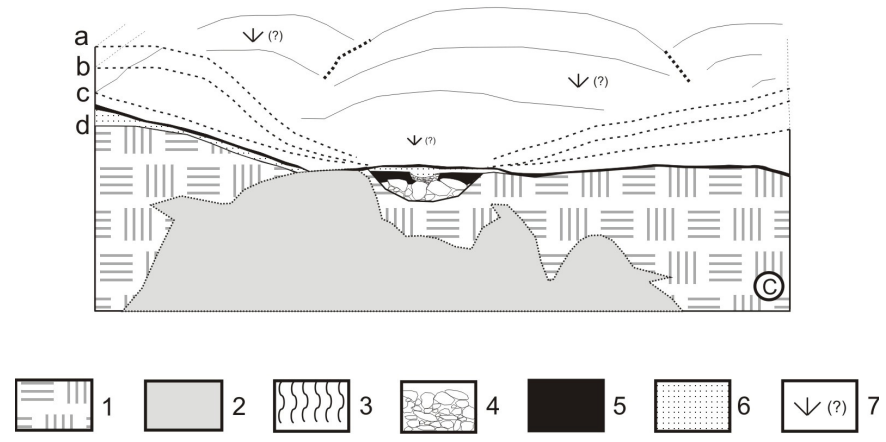

Figura 7 - Esquema de modelo evolutivo das bacias de baixa ordem hierárquica para o Planalto de Palmas (PR) / Água Doce (SC). 1: riodacito. 2: derrame intemperizado. 3: solo + saprolito. 4: conglomerado. 5: horizonte superficial húmico. 6: litossoma coluvial. 7: vegetação de campo, similar a atual (?).

A partir de 11.000 anos AP a área passou por sucessivos eventos de degradação das encostas acompanhados de colmatação (agradação) dos fundos de vale, gerando um litossoma coluvionar. O evento mais expressivo foi gerado logo após essa idade e registra o desmantelamento dos horizontes superficiais húmicos distribuídos nas encostas que circundam os paleocanais de $2^{\text {a }}$ ordem hierárquica (unidade litológica IV). A inversão do relevo já estava em processamento e se efetivou nos últimos 1.000 anos, quando se registra o desenvolvimento de Neossolo com horizonte A húmico, acompanhando a atual configuração topográfica (Figura 7C). Nesse momento, com o recuo dos divisores para norte, aumenta a área drenada pelo sistema hidrográfico do rio Chapecózinho (SC) 
e se encadeia o desmantelamento e rehierarquização das bacias de baixa ordem do sistema hidrográfico do rio Chopinzinho (PR). Nesse último milênio a morfogênese principal é comandada pelo escoamento superficial nas encostas e pela drenagem hipodérmica nos fundos de vales colmatados, similarmente ao registrado a 41.000 anos AP.

\section{CONSIDERAÇÕES FINAISCLUSÕES}

A seção estratigráfica HS1 revelou unidades litoestratigráficas fácies aluvial, colúvio-aluvial, coluvial e tecnogênica, caracterizadas como cascalho lamoso, lama cascalhenta e lama. Propriedades que expressam estreita relação tanto com os processos deposicionais quanto com a proximidade da área fonte dos sedimentos.

Foram reconhecidas duas unidades pedoestratigráficas, caracterizadas por Neossolos com horizontes superficiais húmicos, com elevado teor de carbono orgânico, sobrepostas às unidades litológicas.

O conjunto dessas unidades estratigráficas constitui duas sequências cronoestratigráficas, Pleistocênica Superior e Holocênica, e cinco aloformações.

Registros que trouxeram importantes informações a respeito da evolução de bacias de baixa ordem hierárquica no Planalto de Palmas/Água Doce, sul do Brasil, nos últimos 41.000 anos AP, tais como:

1) durante o final do Pleistoceno Superior, sobretudo entre Último Interestádio (EIM 3) e o Último Máximo Glacial (EIM2), o sistema fluvial de baixa ordem hierárquica e o ambiente de encosta se encontravam em equilíbrio dinâmico, registrando apenas um pulso de morfogênese;

2) nesse período o fundo de vale passou por uma fase de agradação e pedogênese, formando solos rasos (Neossolo flúvico) com horizonte superficial húmico em fase com paleossolos similares de outras localidades, atestando uma fase de estabilidade morfogenética de cunho regional;

3) na passagem para o Holocêno, ou em seu início, ocorreu intensa morfogênese (degradação) das encostas e colmatação (agradação) dos fundos de vale das bacias de baixa ordem hierárquica que perdurou até cerca de 1.000 anos AP;

4) coincidindo com esta fase processou-se a migração do divisor de águas regional para o Norte, com conseqüente desmantelamento das bacias de $1^{\text {a }}$ ordem do sistema hidrográfico do rio Chapecózinho (PR), rehieraquização da rede de drenagem e inversão de relevo;

Em geral, percebe-se uma evolução em que coincidem eventos morfogenéticos de ordem paleoclimatica e tectônica atuando na evolução das bacias hidrográficas de baixa ordem hierárquica no Planalto de Palmas/Água Doce nos últimos 41.000 anos AP. Igualmente, constata-se que o período de morfogênese mais importante na área não esta em fase com as clássicas idéias de que os períodos glaciais seriam os responsáveis pela maior erosão nas encostas e sedimentação nos fundos de vales, enquanto que os períodos interglaciais seriam responsáveis pela pedogênese, fato também constatado por Oliveira et al. (2006) para o Planalto Norte de Santa Catarina.

\section{AGRADECIMENTOS}

Ao CNPq (Proc.472267/2009-4), à Fundação Araucária /SETI/Gov.Paraná (Convênio n. 407/2009) e ao Programa de Pós-Graduação Stricto Sensu em Geografia da Universidade Estadual do Oeste do Paraná pelo apoio financeiro. 


\section{REFERÊNCIA BIBLIOGRÁFICA}

AB'SÁBER, A. N. Revisão dos conhecimentos sôbre o horizonte sub-superficial de cascalhos inhumados do Brasil Oriental. Notícia Geomorfológica, n.11, p.59-80, 1966.

AB'SÁBER, A. N.; BIGARELLA, J. J. Considerações sobre a geomorfogênese da Serra do Mar no Paraná. Boletim Parananense de Geografia, n.4/5, p.94-110, 1961.

ALMEIDA, F. F. M. O Planalto basáltico da Bacia do Paraná. Boletim Paulista de Geografia, n. 24, p. 03-34, 1956.

ÂNGULO, R. J. Ambientes de sedimentação da planície costeira com cordões litorâneos no Estado do Paraná. Boletim de Geociências, UFPR, n.40, p.69-114, 1992.

ÂNGULO, R. J.; ABSHER, T. M. Sedimentos paleoestuarinos da planície costeira do Estado do Paraná. Boletim de Geociências, UFPR, n.40, p.115-135, 1992.

BIGARELA, J. J.; ALESSI, A. H.; BECKER, R.D.; DUARTE, Gerusa Maria Textural characteristics of the coastal dune, sand ridge and beach sediments. Boletim Paranaense de Geociências, n.27, 1969, 80p.

BIGARELLA, J. J.; ANDRADE, G. O. Contribution to the study of the Brazilian Quaternary. Geological Society of America Special Paper 84, p.434-451, 1965.

BIGARELLA, J. J.; FREIRE, S. S.; SALAMUNI, R.; VIANA, R. Contribuição ao estudo dos sedimentos praiais recentes / II-Praias de Matinho e Caiobá. Boletim da UFPR, Geografia Física, n.6, 1966, 109p.

BIGARELLA, J. J.; MOUSINHO, M. R. Significado paleogeográfico e paleoclimático dos depósitos rudáceos. Boletim Paranaense de Geografia, 16/17, p.7-16, 1965a.

BIGARELLA, J. J.; MOUSINHO, M. R. Considerações a respeito dos terraços fluviais, rampas de colúvio e várzeas. Boletim Paranaense de Geografia, 16/17, p.157-197, 1965b.

BIGARELLA, J. J.; MOUSINHO, M. R.; SILVA, J. X. Considerações a respeito dos terraços fluviais, rampas de colúvio e várzeas. Boletim Paranaense de Geografia, 16/17, p. 85-116, 1965a.

BIGARELLA, J. J.; MOUSINHO, M. R.; SILVA, J. X. Pediplanos, pedimentos e seus depósitos correlativos no Brasil. Boletim Paranaense de Geografia, 16/17, p. 117-151, 1965 b.

BIGARELLA, J. J.; SALAMUNI, R. Características texturais dos sedimentos da Bacia de Curitiba. Instituto de Geologia, Boletim da UFPR, n.7, p.1-164, 1962.

BORCHARDT, G. Mineralogy and soil tectonics. In: DIXON, J.B.; SCHULZE, D.G. (Ed) Soil mineralogy with environmental applications. SSSA Book Series: 7, 2002. p.712-735.

CALEGARI, M. R. Ocorrência e significado paleoambiental do horizonte A húmico em Latossolos. Piracicaba, 2008. 259 f. Tese (Doutorado em Agronomia), Escola Superior de Agricultura Luiz de Queiroz, Universidade de São Paulo, Piracicaba, 2008.

CAMARGO, G. O significado paleoambiental de depósitos de encosta e de preenchimento de canal no município de Lapa (PR) no sul do Segundo Planalto Paranaense. 2005. 329 f. Tese (Doutorado em Geografia), Universidade Federal de Santa Catarina, Florianópolis, 2005.

CORTESE, G.; ABELMANN, A. Radiolarian-based paleotemperatures during the last $160 \mathrm{kyr}$ at ODP Site 1089 (Southren Ocean, Atlantic Sector). Palaeogeography, Palaeoclimatology, Palaeoecology, v.182, p.259-286, 2002.

DIETRICH, W. E. ; DUNNE, T. The channel head. In : BEVEN, K. ; KIRKBY, M.J. (Eds) Channel network hydrology. John Wiley and Sons, New York, p.175-219, 1993.

EMBRAPA - Empresa Brasileira de Pesquisa Agropecuária. Centro Nacional de Pesquisa em Solos. Sistema Brasileiro de Classificação de Solos. 2.Ed. Brasília :Embrapa Produção de Informação; Rio de Janeiro:Embrapa Solos, 2006, 306p.

FORTES, E.; CAVALINI, A.; VOLKMER, S.; MANIERI, D. D.; SANTOS, F. R. Controles morfoestruturais da compartimentação da Serra Geral: uma abordagem preliminar. Terra@Plural, UEPG, v.2, n.2, p.279-292, 2008.

FORTES, E.; STEAVAX, J. C.; VOLKMER, S. Neotectonics and channel evolution of the Lower Ivinhema River: a right-bank tributary of the upper Paraná Ruver, Brazil. Geomorphology, v.70, p.325-338, 2005. 
GHIBAUDO, G. Subaqueous sediment gravity flow deposits: practical criteria for their field description and classification. Sedimentology, v.39, p.423-454, 1992.

GUERRA, S.; PAISANI, J. C. Verificação da influência dos derrames vulcânicos da Formação Serra Geral na origem de patamares na área drenada pelo rio Tamanduá - SW PR, Geografia, UEL, p. 163-173, 2010.

HIRUMA, S. T. Revisão dos conhecimentos sobre o significado das linhas de seixos. Revista do Instituto Geológico, SP, n.27-28, v.1/2, p.53-64, 2007.

HUGHES, P. D. Geomorphology and Quaternary stratigraphy: the roles of morpho-, litho-, and allostratigraphy. Geomorphology, n.123, pp.189-199, 2010.

LIMA, A. G. Controle geológico e hidráulico na morfologia do perfil longitudinal em rio sobre rochas vulcânicas básicas da Formação Serra Geral no Estado do Paraná. 2009. 219f. Tese (Doutorado em Geografia), Universidade Federal de Santa Catarina, Florianópolis, 2009.

MAACK, R. Geografia Física do Estado do Paraná, 1968. 350p.

MAACK, R. Notas preliminares sobre clima, solos e vegetação do Estado do Paraná. Arquivos de Biologia e Tecnologia, v. III, p.103-200, 1948.

MEIS, M. R. M.; MONTEIRO, A. M. F. Upper quaternary "rampas": Doce river valley, Southeastern Brazilian plateau. Z.Geomorph. N.F., v.23 , n.2, p.131-151, 1979.

MELLO, C. L. Fácies sedimentares, arquitetura deposicional e relações morfoestratigráficas em um sistema de leques aluviais holocênicos: Aloformação Manso - médio vale do rio Paraíba do Sul (SP/ RJ). 1992. 188 f. Dissertação (Mestrado em Ciências), Universidade Federal do Rio de Janeiro, Rio de Janeiro, 1992.

MELO, M. S.; COIMBRA, A. M.; CUCHIERATO, G. Genesis of quaternary colluvial-eluvial sedimentary covers in southeastern Brazil. Quaternaire, v.12, n.3, p.179-188, 2001.

MELO, M. S.; MEDEIROS, C. V.; GIANNINI, P. C. F.; GARCIA, M. J.; PESSENDA, L. C. R. Sedimentação quaternária no espaço urbano de Ponta Grossa, Pr. Geociências, UNESP, v.22, n.1, p.33-42, 2003.

MODENESI-GAUTTIERI, M. C. Hillslope deposits and the quaternary evolution of the Altos Campos Serra da Mantigueira, from Campos do Jordão to the Itatiaia massif. Revista Brasileira de Geociências, v.30, n.3, p.504-510, 2000.

MOURA, J. R. S.; MEIS, M. R. M. Litoestratigrafia preliminar para os depósitos de encosta do quaternário superior do Planalto SE do Brasil (MG-RJ). Revista Brasileira de Geociências, v.10, p.258-267, 1980.

MOURA, J. R. S.; MELLO, C. L. Classificação aloestratigráfica do quaternário superior na região de Bananal (SP/RJ). Revista Brasileira de Geociências, v.23, n.3, p.236-254, 1991.

MOUSINHO, M. R.; BIGARELLA, J. J. Movimentos de massa no transporte dos detritos da meteorização das rochas. Boletim Paranaense de Geografia, 16/17, p.43-84, 1965.

NARDY, A.J.R.; MACHADO, F.B.; OLIVEIRA, M.A.F. As rochas vulcânicas mesozóicas ácidas da Bacia do Paraná: litoestratigrafia e considerações geoquímico-estratigráficas. Geociências, UNESP, v.38, n.1, p.178-195, 2008.

NICHOLS, G. Sedimentology \& stratigraphy. Blackwell Science Ltd, 1999, 355p.

OLIVEIRA, L.; PAISANI, J. C.; GUERRA, S. Determinação da fração orgânica de formações superficiais - comparação entre os métodos de oxidação versus queima por peróxido de hidrogênio $\left(\mathrm{H}^{2} \mathrm{O}^{2}\right)$. ENCONTRO DE GEOGRAFIA DA UNIOESTE-FBE, 15, ENCONTRO DE GEOGRAFIA DO SUDOESTE DO PARANÁ, 9, 2010, Francisco Beltrão, Anais ..., Francisco Beltrão, 2010, CD-Rom, 3p.

OLIVEIRA, M. A. T.; PESSENDA, L. C. R.; BEHLING, H.; LIMA, G. L.; FERREIRA, G. M. S. S. Registro de mudanças ambientais pleistocênicas e holocênicas em depósitos de cabeceira de vale: Campo Alegre, Planalto Norte catarinense (SC). Revista Brasileira de Geociências, v.36, n.3, p.474-487, 2006.

PAISANI, J. C.; OLIVEIRA, M. A. T. Desenvolvimento de incisão erosiva (voçoroca) descontínua e desconectada da rede hidrográfica em áreas de cabeceira de drenagem: o caso da Colônia Quero-Quero, Palmeira (PR). Revista Brasileira de Geociências, Brasília, v. 31, n. 1, p. 51-57, 2001.

PAISANI, J. C.; PONTELLI, M. E. Propriedades micromorfológicas de colúvios em encosta no médio vale do Rio Marrecas (SW PR) - bases para distinção de formações superficiais alóctones e autóctones 
em substrato basáltico, Pesquisas em Geociências, UFRGS, no prelo.

PAISANI, J. C.; GEREMIA, F. Evolução de encostas no Planalto Basáltico com base na análise de depósitos de colúvio - médio vale do rio Marrecas, SW do Paraná. Geociências, UNESP, v.29, n.3, p.321-334, 2010. PAISANI, J. C.; OLIVEIRA, M. A. T. Identificação de paleossolos em áreas de cabeceira de drenagem: o caso da Colônia Quero-Quero, Palmeira (PR), Geosul, UFSC, v.14, n.27, p.470-475, 1998.

PAISANI, J. C.; PONTELLI, M. E. Propriedades micromorfológicas de colúvios em encosta no médio vale do Rio Marrecas (SW PR) - bases para distinção de formações superficiais alóctones e autóctones em substrato basáltico, Pesquisas em Geociências, UFRGS, no prelo.

PAISANI, J. C.; PONTELLI, M. E.; ANDRES, J. Superfícies aplainadas em zona morfoclimática subtropical úmida no Planalto Basáltico da Bacia do Paraná (SW Paraná/ NW Santa Catarina): primeira aproximação. Geociências, v.27, n.4., p.541-553, 2008a.

PAISANI, J. C.; PONTELLI, M. E.; ANDRES, J.; PASA, V.; MARINHO, F. R Características geológicas da Formação Serra Geral na área drenada pelo Rio Marrecas (SW Paraná): fundamentos para a análise geomorfológica. Geografia, UEL, v.17, n.2, p.49-65, 2008b.

PAISANI, J. C.; PONTELLI, M. E.; GEREMIA, F.; FORTES, J. A. E. Análise de lineamentos na bacia do rio Quatorze - sudoeste do Paraná. Revista Varia Scientia, Unioeste, v.5, v.10, p.65-74, 2005.

PAISANI, J. C.; PONTELLI, M. E; PASA, V.; ANDRES, J. Verificação da Influência da Seqüência de Derrames Vulcânicos da Formação Serra Geral na Ocorrência de Patamares na Área Drenada pelo Rio Marrecas -SW PR, SIMPÓSIO NACIONAL DE GEOMORFOLOGIA, 7, ENCONTRO LATINO AMERICANO DE GEOMORFOlOGIA, 2, 2008, Belo Horizonte, Anais ..., Belo Horizonte, 2008c, CD-Rom, 10p.

PAISANI, J. C.; PONTELLI, M. E.; GEREMIA, F. Cabeceiras de drenagem da bacia do rio Quatorze - Formação Serra Geral (SW do Paraná); distribuição espacial, propriedades morfológicas e controle estrutural. RAE'GA, n. 12, p.211-219, 2006.

PHILLIPS, J. D. Progressive and regressive pedogenesis and complex soil evolution. Quaternary Research, v.40, p.169-176, 1993.

PONTELLI, M. E.; PAISANI, J. C. Controle de fraturas na organização da drenagem da bacia do rio Quatorze, Sudoeste do Paraná. Perspectiva Geográfica, UNIOESTE, n.4, p.129-138, 2008.

SALAMUNI, E.; EBERT, H.D.; HASUI, Y. Morfotectônica da Bacia sedimentar de Curitiba. Revista Brasileira de Geociências, n.34, v.4, p.469-478, 2004.

SCHNEIDER, R.L.; MÛHLMANN, H.; TOMMASI, E.; MEDEIROS, R.A.; DAEMON, R.F.; NOGUEIRA, A.A. Revisão estratigráfica da Bacia do Paraná. XXVIII Congresso Brasileirode Geologia, Anais..., Porto Alegre, p.47-65.

SELBY, M.J. Hillslope sediment transport and deposition. IN: PEY, N. (Ed) Sediment transport and depositional processes. Blackwell Scientific Publications, 1994, p.61-87.

STOOPS, G. Guidelines for analysis and description of soil and regolith thin sections. Soil Science Society of America, Madison, WI, 184p., 2003.

SUGUIO, K.; BIGARELLA, J.J. Ambientes Fluviais. Florianópolis: Ed.UFSC, 1990, 183p.

SUGUIO, K. Introdução à sedimentologia. São Paulo: Edgard Blücher/EDUSP, 1973, 317p.

VOLKMER, S. Mineralogia e morfologia de coberturas de alteração desenvolvidas em rochas vulcânicas ácida: os exemplos de Palmas e Pinhão, Pr. 1999. 184 f. Tese (Doutorado em Geoquímica e Geotectônica), Universidade de São Paulo, São Paulo, 1999.

Trabalho enviado em outubro de 2012

Trabalho aceito em novembro de 2012 